\section{(6) OPEN ACCESS}

\title{
Tobacco control challenges in East Asia: proposals for change in the world's largest epidemic region
}

\author{
Kota Katanoda, ${ }^{1}$ Yuan Jiang, ${ }^{2}$ Sohee Park, ${ }^{3}$ Min Kyung Lim, ${ }^{4}$ You-Lin Qiao, ${ }^{5}$ \\ Manami Inoue ${ }^{6}$
}

- Additional material is published online only. To view please visit the journal online (http://dx.doi.org/10.1136/ tobaccocontrol-2012-050852).

${ }^{1}$ Surveillance Division, Center for Cancer Control and Information Services, National Cancer Center, Tokyo, Japan ${ }^{2}$ Tobacco Control Office, Chinese Center for Disease Control and Prevention, Beijing, China

${ }^{3}$ Department of Epidemiology and Health Promotion, Graduate School of Public Health, Yonsei University, Seoul, Korea

${ }^{4}$ National Cancer Information Center, National Cancer Control Institute, National Cancer Center, Goyang, Korea ${ }^{5}$ Cancer Institute/Hospital, Chinese Academy of Medical Sciences, Peking Union Medical College, Beijing, China ${ }^{6}$ Epidemiology and Prevention Division, Research Center for Cancer Prevention and Screening, National Cancer Center, Tokyo, Japan

\section{Correspondence to} Dr Kota Katanoda, Surveillance Division, Center for Cancer Control and Information Services, National Cancer Center, 5-1-1 Tsukiji Chuo-ku Tokyo 104-0045, Japan; kkatanod@ncc.go.jp

Received 30 October 2012 Accepted 20 March 2013 Published Online First 17 April 2013
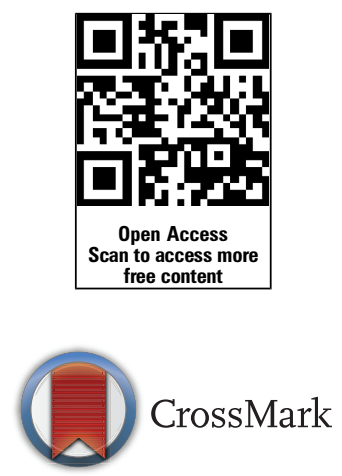

To cite: Katanoda $K$ Jiang Y, Park $S$, et al. Tob Control 2014;23:359-368.

\section{ABSTRACT}

East Asia is one of the world's largest tobacco epidemic regions. Although several international studies have evaluated the status of tobacco control in this region, the findings have not been integrated with knowledge on domestic activities at the national and municipal levels. We analysed the current tobacco control situation in three East Asian countries, Japan, China and the Republic of Korea, using both international and domestic data sources. We collected data between 2008 and 2011 in each country according to the framework of WHO's MPOWER (Monitoring, Protect, Offer, Warn, Enforcement and Raise) approach for guiding implementation of the WHO Framework Convention on Tobacco Control. Analysis revealed that $37-53 \%$ of adult men were current smokers and that smoking prevalence among middle-aged men reached $63 \%$. Less than $20 \%$ of male smokers plan to quit and the use of nicotine replacement drugs was $14 \%$ at maximum. Forty-six percent or more of men and $20 \%$ or more of women were exposed to passive smoking at workplaces and at home, respectively. Many tobacco industry activities remain unrestricted and prevalent. Our findings indicate an urgent need for the following set of policies: raise cigarette prices to increase the quit attempt rate, particularly among adult men; develop a multicomponent quitting assistance system to provide adequate assistance for smoking cessation; implement effective smoke-free policies in workplaces and public places to reduce exposure to passive smoking; and rebuild the administrative structure to denormalise tobacco industry activities. The importance of these standard approaches should be reaffirmed by all tobacco control policymakers in East Asia.

\section{INTRODUCTION}

East Asia is one of the world's largest tobacco epidemic regions. Nearly half of men in this region are cigarette smokers $(38.2 \%$ in Japan, $52.9 \%$ in China and $47.7 \%$ in the Republic of Korea). ${ }^{1}$ China and Japan are the largest and fifth largest tobaccoconsuming countries, respectively, with China alone accounting for approximately $38 \%$ of total global tobacco consumption. ${ }^{1}$ Due to these factors, the estimated number of smoking-attributable deaths in China and Japan is 670000 and 130000 per year, respectively. ${ }^{2-4}$ In China, the number of cancer deaths attributable to smoking was recently estimated to be 495000 annually. ${ }^{5}$ If tobacco smoking in China continues at the current rate, the annual number of smoking-attributable deaths is estimated to reach 3 million by the middle of the twenty-first century. ${ }^{6}$
Despite the large health burden of tobacco use in East Asia, comprehensive and comparative information on the present status of tobacco control in this region is scarce. Although several international studies have provided valuable data related to tobacco control in individual countries, ${ }^{7-11}$ no study has integrated the data with domestic activities at the national and municipal levels to build region-specific strategies. The present study aimed to analyse the current status of tobacco control in three countries in East Asia (Japan, China and the Republic of Korea) to develop policy strategies for changing the world's largest tobacco epidemic region.

\section{METHODS}

We defined East Asia as a geographical area including Japan, mainland China, Taiwan, the Republic of Korea, and the Democratic People's Republic of Korea. The present study analysed data from three countries (Japan, mainland China and the Republic of Korea). We have discussed the status in Taiwan based on the available literature. In the following sections (including tables and figures), we refer to mainland China as China and the Republic of Korea as South Korea, for simplicity.

We set six themes (Monitoring, Protect, Offer, Warn, Enforcement and Raise) in accordance with the MPOWER package for implementation of the Framework Convention on Tobacco Control (FCTC). ${ }^{78}$ FCTC ratification occurred in 2004 for Japan and 2005 for China and South Korea. One or two researchers collected data for the six themes between 2008 and 2011 for each of the three countries examined (Japan: KK; China: JY; South Korea: MKL and SHP). Survey data were selected according to the following criteria: publicly available in a quotable form (mandatory); variables clearly defined to allow for comparative analyses (mandatory); and highly representative of the population (national representative data preferable). For information other than survey data, official information, such as governmental publications, was consulted. Data for the prevalence of adult smoking, ${ }^{12-18}$ youth smoking, ${ }^{19-21}$ passive smoking, ${ }^{13} 141821-25$ and cessation behaviours ${ }^{13} 1426$ were obtained from representative surveys conducted at the national level in each country. Data for cigarette prices, taxes and sales were collected from governmental or official publications. ${ }^{27-31}$ Information on the availability of pharmacotherapy was obtained from clinical guidelines for each country, ${ }^{32-35}$ and information on the health warning labels was obtained from laws or official reports of each country. ${ }^{36-38}$ For collected survey data, those related to active smoking 
prevalence, passive smoking prevalence and smoking cessation were classified as Monitoring, Protect, and Offer, respectively. Collected data were descriptively analysed and priority issues for tobacco control were extracted through discussion between authors.

\section{RESULTS}

Collected data items and their information sources are summarised in the supplementary appendix.

\section{Monitoring (active smoking)}

Nearly half of adult men in China and South Korea were active smokers in 2010 (52.9\% and 48.3\%, respectively, table 1). Smoking prevalence among men in Japan was as high as $37 \%$, even after the price increase in 2010 (from 300 to $410 \mathrm{JPY} /$ pack). When divided into age groups, smoking prevalence in men was over $60 \%$ in those aged $50-59$ years in China and aged 30-39 years in South Korea.
The prevalence of ever smokers, that is, current or former smokers, among men in the three countries reached 70-80\% among middle-aged men (50-59 years). Average age at smoking initiation among this age group was around 20 years. Specifically, men younger than 40 years started smoking at even younger ages, as low as 17.5 years in Japan.

Smoking prevalence among women was highest in Japan $(10 \%)$. Average age at smoking initiation among women in the three countries was lower among younger women; for example, the average initiation age was 32.7 years among women in Japan in their 60s and 18.7 years among women in their $20 \mathrm{~s}$.

In Japan, teenage smoking prevalence was substantially lower than among adults; only $13 \%$ of men and $5 \%$ of women aged 18 years said they had smoked 1 day or more during the past month. The smoking prevalence among Japanese male teenagers was approximately half of the corresponding rates in China and South Korea (26\% and 27\%, respectively), even though the Chinese data excluded those who reported trying to smoke or

Table 1 Comparisons between Japan, China and South Korea in the status of active smoking

\begin{tabular}{|c|c|c|c|c|c|c|c|}
\hline & \multicolumn{2}{|c|}{ Japan } & \multicolumn{2}{|c|}{ China } & \multicolumn{2}{|c|}{ South Korea } & \multirow[b]{2}{*}{ Definitions and notes } \\
\hline & Men & Women & Men & Women & Men & Women & \\
\hline \multicolumn{8}{|c|}{ Adult prevalence, \%* (current smoking) } \\
\hline $20-29$ years & 34.2 & 12.8 & 33.6 & 0.7 & 47.3 & 7.4 & \multirow{6}{*}{$\begin{array}{l}\text { J: Having smoked } 100 \text { cigarettes or more in their lifetime and currently daily or sometimes } \\
\text { smoking (2010) } \\
\text { C: Currently smoking (daily or less than daily) (2010) } \\
\text { K: Having smoked } 100 \text { cigarettes or more in their lifetime and currently smoking (2010) }\end{array}$} \\
\hline $30-39$ years & 42.1 & 14.2 & 59.3 & 1.6 & 60.9 & 7.6 & \\
\hline 40-49 years & 42.4 & 13.6 & & & 53.6 & 6.6 & \\
\hline $50-59$ years & 40.3 & 10.4 & 63.0 & 3.2 & 45.0 & 5.2 & \\
\hline $60-69$ years & 27.4 & 4.5 & 40.2 & 6.7 & 30.8 & 2.9 & \\
\hline Total (20-69 years) & 36.7 & 10.4 & 52.9 & 2.4 & 48.3 & 6.3 & \\
\hline \multicolumn{8}{|c|}{ Adult prevalence, \%* (former smoking) } \\
\hline $20-29$ years & 5.2 & 5.4 & 2.6 & 0.2 & 10.2 & 8.5 & \multirow{6}{*}{$\begin{array}{l}\text { J: Having smoked } 100 \text { cigarettes or more in their lifetime and currently non-smoking (2009) } \\
\text { C: Having ever smoked and currently non-smoking (2007) } \\
\text { K: Having smoked } 100 \text { cigarettes or more in their lifetime and currently non-smoking (2010 }\end{array}$} \\
\hline $30-39$ years & 16.2 & 11.4 & 5.0 & 0.3 & 21.5 & 6.8 & \\
\hline $40-49$ years & 22.2 & 7.0 & 7.3 & 0.3 & 28.3 & 2.9 & \\
\hline $50-59$ years & 28.5 & 7.4 & 10.8 & 0.7 & 40.1 & 1.5 & \\
\hline $60-69$ years & 34.5 & 5.0 & 16.4 & 1.3 & 51.9 & 2.9 & \\
\hline Total (20-69 years) & 23.7 & 7.2 & 7.2 & 0.5 & 29.8 & 4.9 & \\
\hline \multicolumn{8}{|c|}{ Youth prevalence, \%† (monthly ever smoking) } \\
\hline 13 years & 1.5 & 1.1 & 7.7 & 2.0 & 6.2 & 3.5 & \multirow{6}{*}{$\begin{array}{l}\text { J: Having smoked } 1 \text { day or more during past month (2008) } \\
\text { C: Having smoked during past month (excluding those who reported trying to smoke or } \\
\text { having smoked one cigarette if they did not currently smoke) (2005) } \\
\text { K: Having smoked } 1 \text { day or more during past month (2010) }\end{array}$} \\
\hline 14 years & 3.3 & 2.1 & 11.6 & 3.0 & 11.5 & 5.5 & \\
\hline 15 years & 3.9 & 2.6 & 14.2 & 3.3 & 13.9 & 6.4 & \\
\hline 16 years & 6.8 & 3.8 & 25.1 & 4.6 & 19.8 & 9.1 & \\
\hline 17 years & 9.9 & 4.4 & 26.0 & 4.8 & 21.2 & 9.3 & \\
\hline 18 years & 12.9 & 5.3 & 25.9 & 4.3 & 26.6 & 8.6 & \\
\hline \multicolumn{8}{|c|}{ Youth prevalence, \%† (habitual smoking) } \\
\hline 13 years & 0.3 & 0.3 & 1.4 & 0.1 & 1.2 & 0.8 & \multirow{6}{*}{$\begin{array}{l}\text { J: Having smoked } 20 \text { days or more during past month (2008) } \\
\text { C: Having smoked } 20 \text { days or more during past month (excluding those who reported trying } \\
\text { to smoke or having smoked one cigarette if they did not currently smoke) (2005) } \\
\text { K: Having smoked } 20 \text { days or more during past month (2010) }\end{array}$} \\
\hline 14 years & 1.3 & 0.6 & 2.6 & 0.3 & 4.1 & 1.6 & \\
\hline 15 years & 1.6 & 0.7 & 4.2 & 0.4 & 7.5 & 2.8 & \\
\hline 16 years & 3.5 & 1.4 & 9.3 & 0.6 & 11.9 & 4.9 & \\
\hline 17 years & 5.8 & 2.4 & 10.5 & 0.7 & 15.0 & 5.6 & \\
\hline 18 years & 8.7 & 2.9 & 11.4 & 0.8 & 21.0 & 5.5 & \\
\hline \multicolumn{8}{|c|}{ Average age at smoking initiation* } \\
\hline $20-29$ years & 17.5 & 18.7 & 17.6 & 19.6 & 17.9 & 18.0 & \multirow{6}{*}{$\begin{array}{l}\text { J: Among ever smokers (current or former habitual smokers) (2003) } \\
\text { C: Among ever smokers (having smoked } 100 \text { cigarettes or more in their lifetime) (2007) } \\
\text { K: Among ever smokers (having smoked } 100 \text { cigarettes or more in their lifetime) (2010) }\end{array}$} \\
\hline $30-39$ years & 18.2 & 20.0 & 18.6 & 22.0 & 18.5 & 20.6 & \\
\hline $40-49$ years & 18.9 & 23.1 & 19.1 & 25.6 & 19.4 & 26.0 & \\
\hline $50-59$ years & 19.9 & 28.9 & 20.3 & 25.3 & 20.1 & 33.1 & \\
\hline $60-69$ years & 20.6 & 32.7 & 21.9 & 28.7 & 20.8 & 32.5 & \\
\hline Total (20-69 years) & 17.3 & 18.3 & 19.1 & 23.6 & 19.3 & 25.5 & \\
\hline
\end{tabular}

*For China, age categories are 15-24 years, 25-44 years, 45-64 years, 65+ years, and 15+ years old, from the top to bottom. For South Korea, the categories '20-29 years' and '2069 years' represent $19-29$ years and $19-69$ years, respectively.

tThe ages correspond to the grades in school, from first year of junior high school to third year of high school.

C, China; J, Japan; K, South Korea; N/A, not available. 
having smoked only one cigarette if they did not currently smoke.

\section{Protect (passive smoking)}

Prevalence of passive smoking exposure in China was remarkably high. Over $70 \%$ of adult men and $50-60 \%$ of adult women were exposed at home and in workplaces (table 2). Although the absolute prevalence of exposure was lower in Japan and South Korea, the pattern of exposure was similar. Passive smoking was also prevalent among youths, with $35 \%$ or more exposed to passive smoking at home in each of the three countries.

Currently in Japan, there is no national legislation prohibiting indoor smoking. At the prefectural level, an ordinance to prevent passive smoking in public places exists in only Kanagawa Prefecture, which has a population of 9 million and is located adjacent to Tokyo. However, the ordinance does not mandate a completely smoke-free environment in public places, and does not cover workplaces. None of the three countries has enacted national legislation for smoke-free workplaces. In Japan, revision of the Occupational Safety and Health Act had been scheduled to take place in 2011, and was supposed to include an obligation for employers to prevent exposure to second-hand smoke; however, as of August 2012 the proposed revision has been postponed. Moreover, the bill drafted by the former ruling party did not actually include a provision concerning employers' obligations. Remarkably, a higher percentage of the Japanese population was supportive of a partial rather than a complete ban, even among non-smokers $(54 \%$ vs $35 \%$ for workplaces, and $56 \%$ vs $43 \%$ for public places), despite the fact that partial bans have been shown to be ineffective for protecting non-smokers from exposure. ${ }^{39}$

\section{Offer (smoking cessation)}

The percentage of smokers planning or thinking of quitting smoking within 1 year was lower than $20 \%$ in the three countries (table 3). Quit attempt rates during the past year among men and women were lower in Japan $(21 \%$ and $34 \%$, respectively) than in China and South Korea. The percentage of smokers who had attempted to quit smoking without assistance was $77 \%$ or higher in the three countries. Use of nicotine replacement drugs (prescription or over the counter) was reportedly only $14 \%$ in Japan and $5 \%$ or lower in China and South Korea.

The use of smoking cessation drugs is partially covered by health insurance in Japan. However, as of 2011, the coverage is restricted to outpatients and heavy smokers (using the Brinkman index; the number of cigarettes smoked per day multiplied by the number of smoking years $\geq 200$ ), and a quitline system has not been implemented.

\section{Warn}

The package labels of tobacco products are similar in the three countries (figure 1). The labels fulfil only one or two items ('location' and 'language') of the warning standards recommended by the FCTC (table 4). The health warnings were characterised by small size (30\% area of the front and back labels), lack of pictorial use, ambiguous expressions, muted colours, and conveying the impression of reduced harm.

\section{Enforcement}

The activities of the tobacco industry are largely unrestricted in the three countries (table 5). Particularly in Japan, the regulation of advertisements and sales promotion by the tobacco industry has been enforced only on a voluntary basis. In addition, a large number of corporate advertisements on television, product advertisements in magazines, and sponsorships of sports and social activities remain unrestricted. Legal regulation of advertisements and promotion of tobacco products has been enacted in China and South Korea, although the restrictions are only partial. For example, in Sichuan, China, elementary schools were built under the sponsorship of the tobacco industry as part of the 2008 great earthquake recovery efforts, and in those schools, huge pro-tobacco banners are posted. ${ }^{40} 41$

Sale of tobacco to minors is legally prohibited in all three countries. In Japan, however, vending machines are widely available nationwide and access is only restricted by their proximity to retailers. Although minors' access to vending machines is restricted by the requirement for an identification card (eg, the TASPO system in Japan), the system has reportedly been ineffective. ${ }^{19}$ Tobacco vending machines are also not prohibited in South Korea. In addition, Japan and South Korea do not restrict the proximity of tobacco retailers to schools.

\section{Raise}

The tax rate of cigarettes in Japan is currently $65 \%$ of the retail price (figure 2). The average retail price of cigarettes was raised from 300 to $410 \mathrm{JPY} /$ pack in 2010. However, the current price corresponds to US\$3.16 according to the purchasing power parities (PPPs) in $2005,{ }^{42}$ which is approximately $33 \%$ of the PPP-converted price in the UK ( $£ 6.3=\mathrm{US} \$ 9.68$, according to the identical PPP conversion). Tax rates in China and South Korea are $71 \%$ and $62 \%$ of the retail price, respectively, which are comparable to the Japanese rate. The PPP-converted price in South Korea (US\$3.17) is nearly the same as that in Japan, whereas the converted price in China (US\$2.32) is only approximately $73 \%$ of that in Japan.

The number of cigarettes sold per capita in Japan reached a peak in the late 1970s (figure 3). After a second peak in the late 1990s, cigarette sales decreased, falling even more after the year 2000. The trend in per capita cigarette sales in South Korea was similar to that observed in Japan, also rapidly decreasing from 2000. Per capita cigarette sales in China temporarily decreased in the 1990s, but began increasing during the past decade.

When we compared the number of cigarettes sold before and after the 2010 price increase in Japan, the total number of cigarette sales had decreased by $10 \%$ in 2010 compared with the value in 2009 (from 233.9 to 210.2 billion cigarettes, respectively). ${ }^{43}$ This rate of decrease was 2.5 -fold higher than the average annual rate of decrease that had occurred during the previous 5 years (from 292.6 billion cigarettes in 2004 to 233.9 billion cigarettes in 2009).

\section{DISCUSSION}

In the present study, we analysed the current status of tobacco control in three East Asian countries, based on quantitative data and published information from international and domestic sources.

\section{Analysis}

The high smoking prevalence among men in all three countries is a major concern. A peak of ever-smoker prevalence $(70 \%)$ was observed among men aged 50-59 years, who will have an increased incidence of chronic diseases caused by smoking in later years due to the high accumulated exposure to active smoking.

Factors underlying the high smoking prevalence among men are the low quit attempt rate and poor support for smoking 
Table 2 Comparisons between Japan, China and South Korea in the status of passive smoking

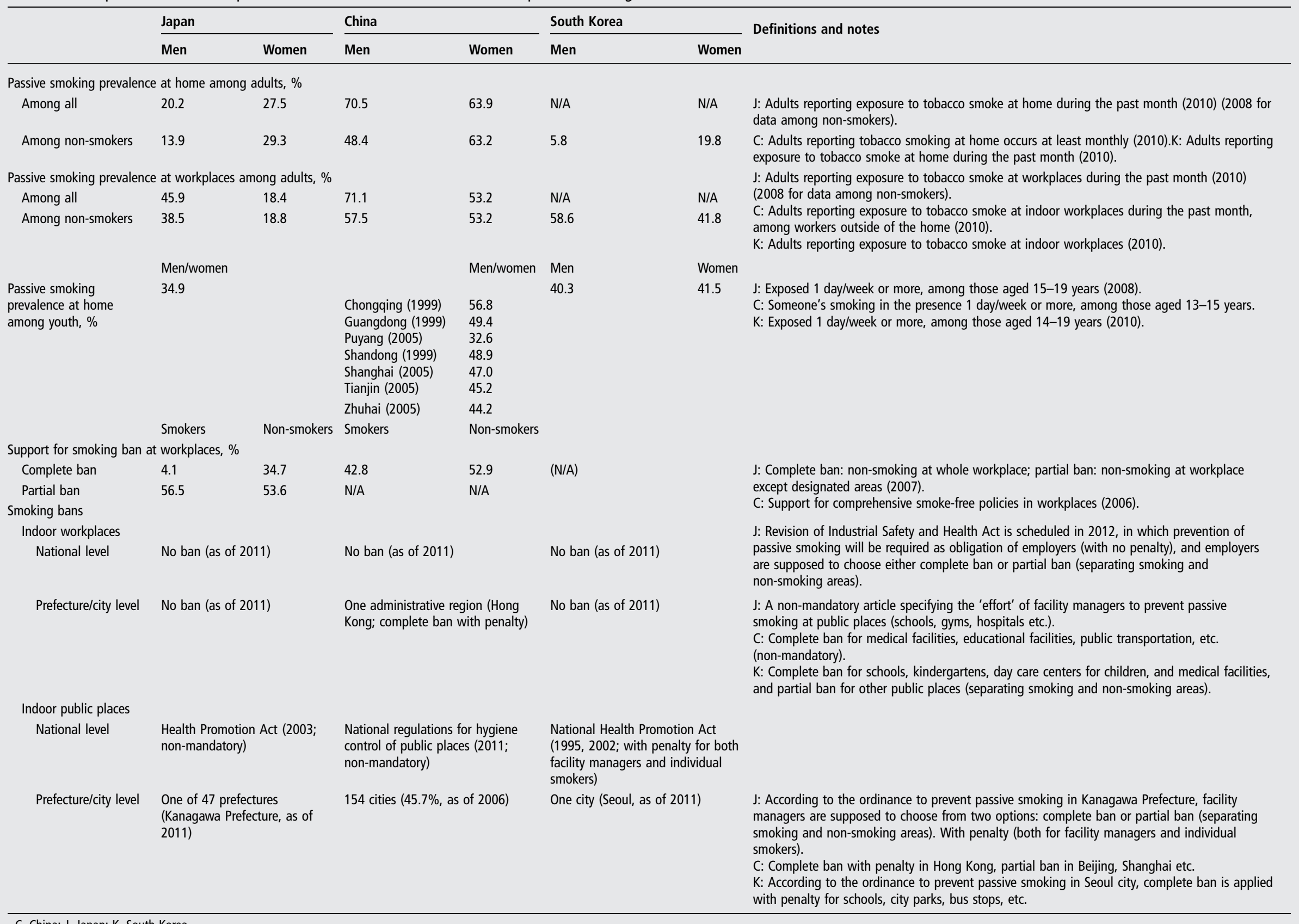


Table 3 Comparisons between Japan, China and South Korea in the status of smoking cessation and quit assistance

\begin{tabular}{|c|c|c|c|c|c|c|c|}
\hline & \multicolumn{2}{|c|}{ Japan } & \multicolumn{2}{|c|}{ China } & \multicolumn{2}{|c|}{ South Korea } & \multirow[b]{2}{*}{ Definition and notes } \\
\hline & Men & Women & Men & Women & Men & Women & \\
\hline $\begin{array}{l}\text { Planning or thinking } \\
\text { about quitting, \% }\end{array}$ & 13.9 & 17.3 & 16.0 & 19.5 & 13.2 & 11.7 & $\begin{array}{l}\text { J: Current smokers who are planning or thinking about } \\
\text { quitting smoking within } 1 \text { year (2010) } \\
\text { C: Current smokers who are planning or thinking about } \\
\text { quitting smoking within } 1 \text { year }(2010) \\
\text { K: Current smokers who are planning or thinking about } \\
\text { quitting smoking within } 6 \text { months (2010) }\end{array}$ \\
\hline Quit attempt rate, \% & 20.5 & 34.4 & 35.9 & 46.4 & 53.4 & 63.3 & $\begin{array}{l}\text { J: Smokers who tried to quit during the past year }(2010)^{*} \\
\text { C: Smokers who tried to quit during the past year }(2010)^{*} \\
\text { K: Smokers who made a quit attempt for } 1 \text { day or longer } \\
\text { during the past year }(2010)^{*}\end{array}$ \\
\hline $\begin{array}{l}\text { Quit attempt without } \\
\text { assistance, } \%\end{array}$ & 77.3 & 77.3 & 91.8 & 91.1 & 89.5 & 94.6 & $\begin{array}{l}\text { J: Smokers who used pharmacotherapy, counselling/ } \\
\text { advice, or other cessation methods among those who } \\
\text { made a quit attempt during the past year (2010)* } \\
\text { C: Smokers who used pharmacotherapy, counselling/ } \\
\text { advice, or other cessation methods among those who } \\
\text { made a quit attempt during the past year (2010)* } \\
\text { K: Smokers who made a quit attempt with no assistance } \\
\text { (by him/herself) among those who made a quit attempt } \\
\text { during the past year (2010) }\end{array}$ \\
\hline $\begin{array}{l}\text { Use of cessation } \\
\text { support drugs, \% }\end{array}$ & 13.6 & 13.6 & 3.0 & 5.4 & 4.5 & 5.4 & $\begin{array}{l}\text { J: Smokers who used nicotine replacement therapy during } \\
\text { their last quit attempt among those who made a quit } \\
\text { attempt during the past year (2010)* } \\
\text { C: Smokers who used pharmacotherapy among those who } \\
\text { attempted to quit smoking in the past year (2010) } \\
\text { K: Smokers who used nicotine replacement therapy during } \\
\text { their quit attempt (2010) }\end{array}$ \\
\hline $\begin{array}{l}\text { Available cessation } \\
\text { therapy or drugs, } \%\end{array}$ & \multicolumn{2}{|c|}{$\begin{array}{l}\text { OTC: nicotine gum and } \\
\text { patch } \\
\text { Rx: nicotine patch and } \\
\text { varenicline, both covered } \\
\text { by health insurance under } \\
\text { several conditions }\end{array}$} & \multicolumn{2}{|c|}{$\begin{array}{l}\text { OTC: nicotine gum, patch, } \\
\text { and troche } \\
\text { Rx: bupropion and } \\
\text { varenicline }\end{array}$} & \multicolumn{2}{|c|}{$\begin{array}{l}\text { OTC: nicotine gum and patch } \\
\text { Rx: free nicotine replacement } \\
\text { therapy is available in } 256 \\
\text { public health centres under the } \\
\text { nationwide cessation services } \\
\text { managed by the national } \\
\text { government. Varenicline and } \\
\text { bupropion are available with } \\
\text { payment }\end{array}$} & \\
\hline
\end{tabular}

*The definition of smokers was 'current smokers and those who quit in past 12 months'.

OTC, over the counter; Rx, prescription.

cessation. Among women in China and men and women in South Korea, more than half of each group had attempted to quit smoking. However, judging from the lack of a rapid decrease in smoking prevalence, ${ }^{144}$ their success rates are considered to be low.

Smoking cessation drugs are covered by the national health insurance programme in Japan and are freely available at public health centres in South Korea. However, use of these prescription drugs has not substantially increased across the time periods studied. ${ }^{14} 45$ Japan also lags in the effort to promote smoking cessation. The FCTC Parties' report showed that there were no media campaigns promoting smoking cessation in Japan. $^{46}$ In China, cessation support drugs are available as over-the-counter formulations and prescriptions, but the country has been slow in developing a medical care support system for cessation treatment. According to the FCTC Parties' report, China mandates healthcare professionals to promote smoking cessation, ${ }^{47}$ but there is no systematic support for implementation of such a policy.

Youth smoking prevalence was high among boys in China and South Korea. In Japan, smoking prevalence among minors was low, which is thought to be a result of antismoking education. However, there is a large difference in smoking prevalence between the age cohorts of 18 years and 20-29 years, perhaps reflecting a lack of continuing antismoking education after high school. According to FCTC reports, all three countries stated that measures had been implemented in the area of education, ${ }^{46-48}$ but there is a problem in that none of the three countries had specific targets for their educational activities.

High exposure rates to environmental tobacco smoke were also common in the three countries. The lack of legislative measures, particularly for workplaces, poses a major challenge. The FCTC reports revealed that Japan lagged significantly behind in smoking bans, ${ }^{46}$ and this was reconfirmed by the present study.

Underlying the high prevalence of active and passive smoking in the three countries is a lack of effective containment of the tobacco industry activities that undermine tobacco control efforts. In the FCTC Parties' reports, all three countries stated that they protected tobacco control efforts against interference from the tobacco industry. ${ }^{46-48}$ South Korea stated in the Parties' report that the country had implemented comprehensive restrictions on tobacco advertisement, promotion and sponsorship. ${ }^{48}$ However, this study revealed that indirect advertising by tobacco companies remains prevalent in all three countries. In the Parties' report Japan cited infringement of the Constitution as an obstacle to enforcing advertising restrictions, ${ }^{46}$ but there has been no court ruling declaring such restrictions unconstitutional. In South Korea, the legality of advertising restrictions has 
Japan

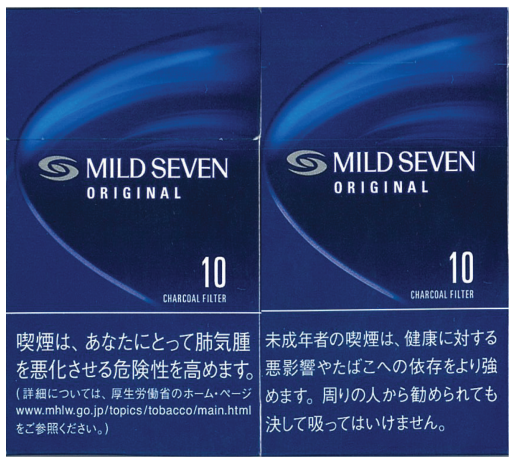

China

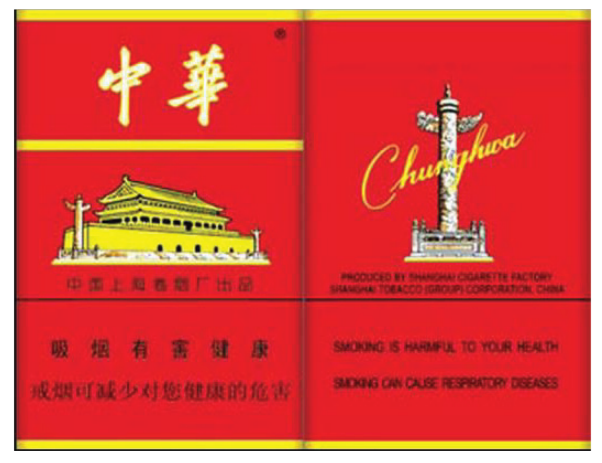

South Korea

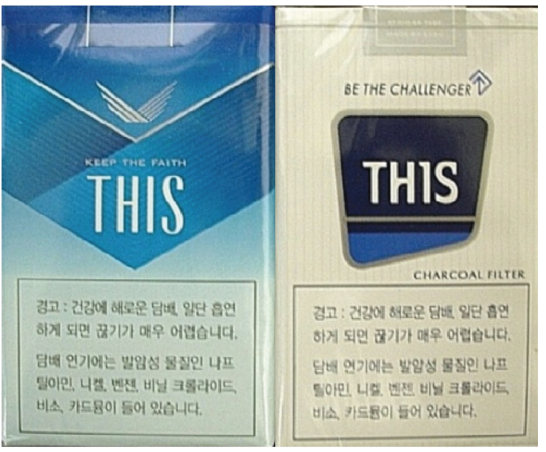

Figure 1 Representative warning labels on cigarette packages in Japan, China and South Korea. Japan front (in Japanese): Smoking increases the risk of worsening your emphysema. (Detailed information is available at the MHLW website, http://www.mhlw.go.jp/topics/tobacco/main.html). Back (in Japanese): Smoking among minors increases adverse health effects and tobacco dependence. You should not smoke even if urged to do so by the people around you. China front (in Chinese): Smoking is harmful to your health. Quitting smoking early is good for your health. Back (in English): Smoking is harmful to your health. Smoking can cause respiratory diseases. South Korea front (in Korean): Warning: Smoking is harmful to your health. Once you start, it is very difficult to quit. Tobacco smoke includes carcinogens such as naphthylamine, nicotine, benzene, arsenic, and cadmium. Back (in Korean): Same as the front label.

been affirmed. The support among Japanese people for partial rather than complete bans on workplace and public place smoking is likely to reflect the effects of the large-scale media campaigns by Japan Tobacco Inc (JT), emphasising the coexistence of smokers and non-smokers.

Similarities among the three countries are notable in warning labels. In the FCTC Parties' reports, the three countries provided the same responses to almost all of the items in the area of Warn. ${ }^{46-48}$ In the lawsuit over Australia's plain packaging law filed at the High Court of Australia, JT was among the plaintiffs. Following the decision by the High Court to uphold the plain packaging law as constitutional, the EU is now considering

Table 4 Compliance of warning labels on tobacco products in Japan, China and South Korea with the FCTC requirements

\begin{tabular}{|c|c|c|c|c|}
\hline & $\begin{array}{l}\text { Requirements of } \\
\text { the FCTC }\end{array}$ & Japan & China & South Korea \\
\hline \multirow[t]{2}{*}{ Location } & Front and back & $\checkmark$ & $\checkmark$ & $\checkmark$ \\
\hline & Top & Not fulfilled & Not fulfilled & Not fulfilled \\
\hline Size & $50 \%$ or more & $\begin{array}{l}\text { Not fulfilled } \\
(30 \%)\end{array}$ & $\begin{array}{l}\text { Not fulfilled } \\
(30 \%)\end{array}$ & $\begin{array}{l}\text { Not fulfilled } \\
(30 \%)\end{array}$ \\
\hline Warnings & $\begin{array}{l}\text { Large, clear, visible } \\
\text { and legible }\end{array}$ & Not fulfilled & Not fulfilled & Not fulfilled \\
\hline Pictorial use & Use pictures & Not fulfilled & Not fulfilled & Not fulfilled \\
\hline Color & $\begin{array}{l}\text { Contrasting with } \\
\text { background }\end{array}$ & Not fulfilled & Not fulfilled & Not fulfilled \\
\hline Rotation & $\begin{array}{l}\text { Rotate multiple } \\
\text { pictures/warnings }\end{array}$ & $\begin{array}{l}\text { Not fulfilled } \\
\text { (4 warnings, } \\
\text { with no } \\
\text { pictures) }\end{array}$ & $\begin{array}{l}\text { Not fulfilled } \\
\text { ( } 2 \text { warnings, } \\
\text { no pictures) }\end{array}$ & $\begin{array}{l}\text { Not fulfilled } \\
\text { ( } 2 \text { warnings, } \\
\text { no pictures) }\end{array}$ \\
\hline Content & Specific and clear & Not fulfilled & Not fulfilled & Not fulfilled \\
\hline Language & $\begin{array}{l}\text { Local principal } \\
\text { language }\end{array}$ & $\checkmark$ & $\begin{array}{l}\text { Not fulfilled } \\
\text { (Chinese and } \\
\text { English) }\end{array}$ & $\checkmark$ \\
\hline Constituents & $\begin{array}{l}\text { Implication of less } \\
\text { harm should not } \\
\text { be included }\end{array}$ & Not fulfilled & Not fulfilled & Not fulfilled \\
\hline
\end{tabular}

adoption of plain packaging. This movement needs to be expanded to East Asia as well.

The price of cigarettes was highest in Japan until 2004, when the price was surpassed by that of South Korea. Although Japan increased cigarette prices by a large margin in 2010, its PPP-converted prices are only around the same as those of South Korea. The reason for cigarette prices in Japan being close to those in South Korea might be that both countries are presumably trying to keep cigarette demand from falling excessively. Smoking prevalence in Japan decreased after the 2010 price increase. However, the decline is not as sharp as that in the number of cigarettes sold. In the same period the proportion of light smokers increased while that of heavy smokers decreased. ${ }^{49}$ A similar phenomenon was seen in South Korea after cigarette prices were raised in $2005 .^{50}$ Raising cigarette prices presumably encouraged people to smoke less rather than quitting in these two countries. When Japan's former ruling Democratic Party increased cigarette prices, they declared that it was to protect the health of the Japanese people, rather than to increase tax revenues. ${ }^{51}$ This marked a major turnaround in the Japanese government's tobacco policies. The Liberal Democratic Party, which returned to power at the end of 2012, has been taking a passive stance towards tobacco control. To prevent the major trend created by the Democratic Party from stalling or regressing, it is important to continue with advocacy efforts.

\section{Proposed policies}

Based on our findings, we suggest implementation of the following set of policies in East Asia in a cooperative manner. First, further raising the price of cigarettes is necessary. Tobacco tax policies have enormous potential to encourage quitting among smokers and simultaneously generate considerable tax revenue. $^{52}$ The potential impact of this approach is particularly large in China, ${ }^{53}$ which has the lowest cigarette price of the three countries. Japan and China should consider earmarking the additional cigarette tax revenue for health promotion activities, as has already been implemented in South Korea.

Second, policies for increasing quit attempts should be combined with policies assuring adequate cessation support. A multi-component quitting assistance system that includes telephone support and guidance for cessation drugs, which has 
Table 5 Current situation of the regulations on tobacco advertisement, promotion and physical sales in Japan, China, and South Korea

\begin{tabular}{|c|c|c|c|}
\hline Theme & Japan & China & Korea \\
\hline Advertisement & $\begin{array}{l}\text { Voluntary restrictions on product advertisement on } \\
\text { TV, radio, public transportations and outdoor boards } \\
\text { Corporate advertisements on TV, product } \\
\text { advertisements on adult magazines are still } \\
\text { unrestricted and prevalent }\end{array}$ & $\begin{array}{l}\text { Legal ban on product advertisement } \\
\text { on TV, radio, movies, newspapers, } \\
\text { magazines, gyms etc. }\end{array}$ & $\begin{array}{l}\text { Legal ban on product advertisement on TV, radio, } \\
\text { newspapers and magazines } \\
\text { Bans on corporate advertisement on TV and radio upheld } \\
\text { by court } \\
\text { Voluntary restrictions on smoking scenes on TV dramas } \\
\text { The number of product advertisements in adult magazines } \\
\text { are restricted by annual frequency (eg, under } 10 \text { times per } \\
\text { year) }\end{array}$ \\
\hline $\begin{array}{l}\text { Promotion or } \\
\text { sponsorship }\end{array}$ & $\begin{array}{l}\text { Sponsorship for sports and social activities (eg, a } \\
\text { professional volleyball team and a Japanese chess } \\
\text { tournament) are unrestricted and prevalent }\end{array}$ & $\begin{array}{l}\text { Sponsorships for social activities (eg, } \\
\text { elementary school) are still } \\
\text { unrestricted and prevalent }\end{array}$ & $\begin{array}{l}\text { Corporate sponsorship for social, cultural, musical, sports } \\
\text { activities (eg, elementary schools sponsored by the } \\
\text { tobacco industry) are still unrestricted and prevalent }\end{array}$ \\
\hline Physical sales & $\begin{array}{l}\text { Sales to minors are legally prohibited (under age 20) } \\
\text { Vending machines are restricted based on proximity } \\
\text { to nearby retailers, but are prevalent nationwide } \\
\text { Minors' access to vending machines is restricted by } \\
\text { an identification card (TASPO), but its misuse has } \\
\text { been reported } \\
\text { No restriction on retailers' proximity to schools }\end{array}$ & $\begin{array}{l}\text { Sales to minors are legally prohibited } \\
\text { (under age 18) } \\
\text { Vending machines are prohibited } \\
\text { Retailers' proximity to schools is } \\
\text { restricted }\end{array}$ & $\begin{array}{l}\text { Sales to minors are legally prohibited (under age 19) } \\
\text { Vending machines are restricted by proximity to nearby } \\
\text { retailers } \\
\text { Minors' access to vending machines is restricted by an } \\
\text { identification card } \\
\text { No restriction on retailers' proximity to schools }\end{array}$ \\
\hline
\end{tabular}

been shown to be effective in South Korea, ${ }^{54}$ should also be implemented in Japan and China. ${ }^{55}$ In addition, populationbased approaches using existing healthcare systems are needed to increase successful quitting attempts. In Japan, for example, there are widely prevalent health check-up systems at worksites and community healthcare centres, with $30-40 \%$ or higher participation rates. ${ }^{56-58}$ Conducting brief smoking cessation interventions at health check-up facilities will lead to increased cessation rates. ${ }^{59}$
Third, effective smoke-free policies in workplaces and public places are required. ${ }^{60}$ Despite enactment of effective smoking bans at the municipal level (eg, workplaces in Hong Kong and public places in Seoul), national and other provincial governments have been slow in adopting such measures. In 2011, the Japanese Labour Policy Council proposed an ineffective revision of the Occupational Safety and Health Act, which allowed employers to build designated indoor smoking areas with ventilation. This amendment clearly falls below the standards of the
$\operatorname{Japan}^{\dagger}$

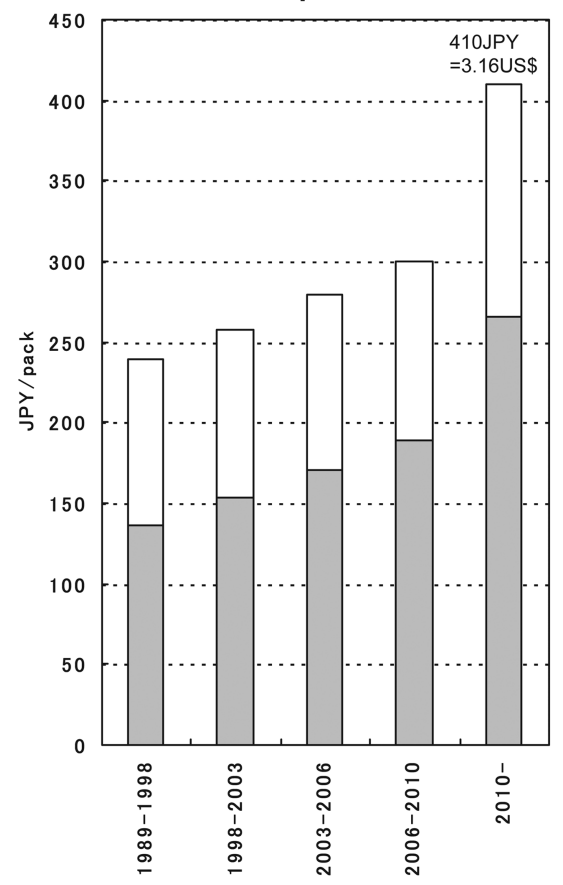

China ${ }^{\ddagger}$

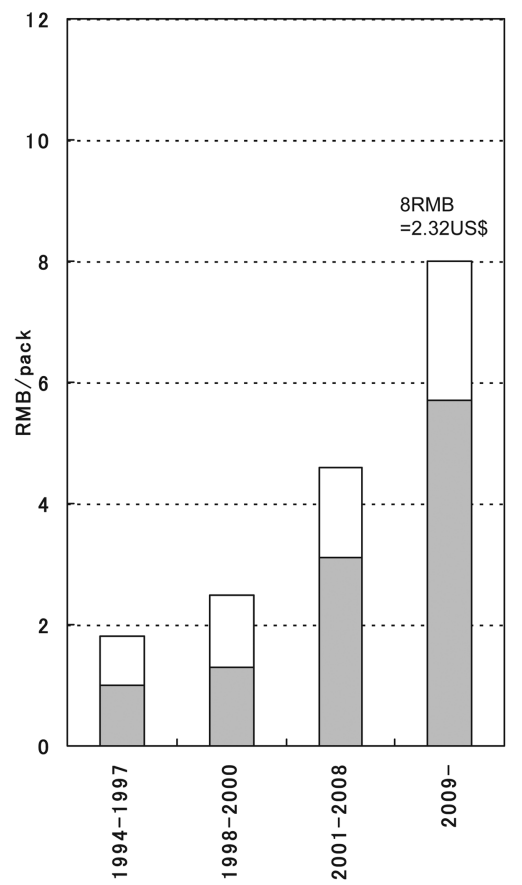

South Korea§

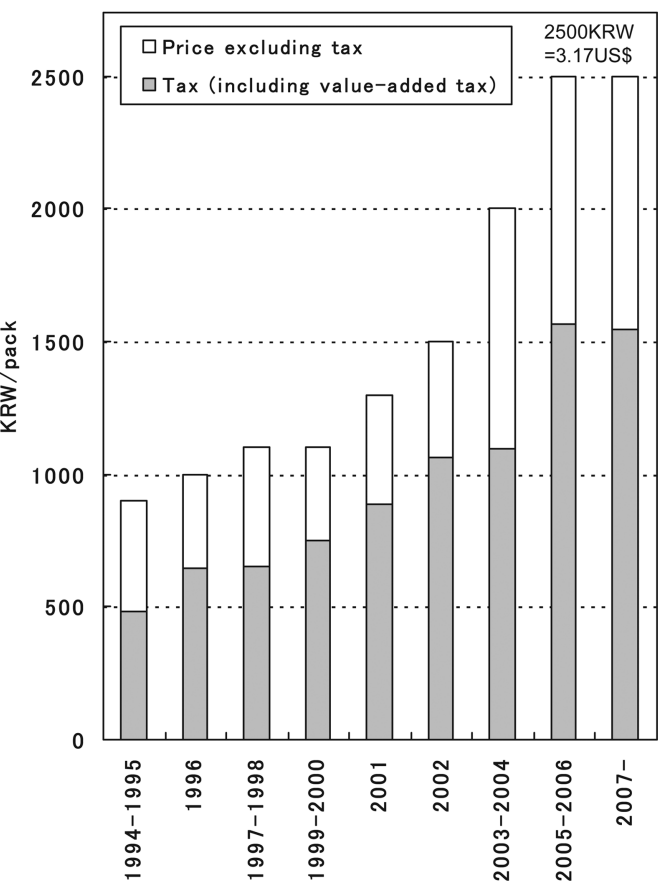

Figure 2 Average price and tax of cigarettes in Japan, China and South Korea. *The figures on the bar for the most recent price and vertical scales were adjusted according to the purchasing power parities: $1 \mathrm{JPY}=\mathrm{US} \$ 129.55,1 \mathrm{RMB}=\mathrm{US} \$ 3.45,1 \mathrm{KRW}=\mathrm{US} \$ 788.92$ (International Comparison Programme 2005). †For Japanese data, 'tax' includes tobacco tax and value-added tax. ¥For Chinese data, 'tax' includes tobacco consumption tax and value-added tax. §For South Korean data, 'tax' includes tobacco consumption tax, local education tax, fee for health promotion, value-added tax, and other additional fees. Sources: Japan: Ministry of Finance, Japan; China: Potential Effects of Tobacco Taxation, the Chinese Association of Tobacco Control etc; South Korea: National Statistical Office, South Korea. 


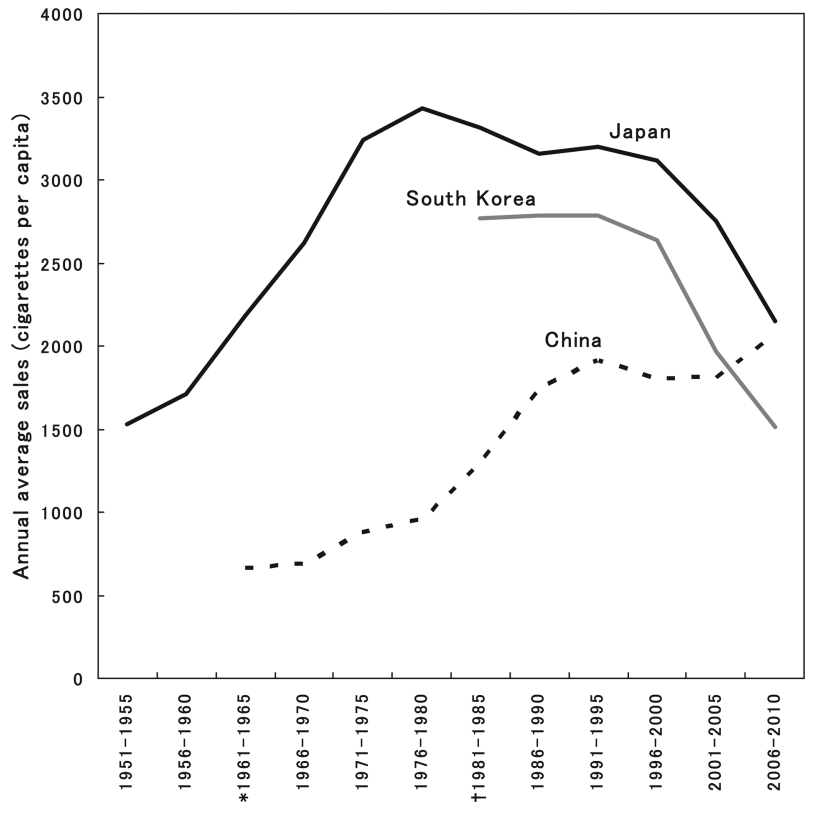

Figure 3 Trends in annual average cigarette sales per capita ( $\geq 15$ years old) in Japan, China and South Korea. *1959-1965 for China; +1983-1985 for South Korea. Sources: Japan: Japan Health Promotion and Fitness Foundation (1920-2007 fiscal year); Annual Report of Japan Tobacco Inc (2008-9 fiscal year); Ministry of Internal Affairs and Communications (population data). China: Institute of Economics, National Agency for Tobacco Monopoly; World Population Prospects, 2008 Revision, United Nations, Department of Economic and Social Affairs (population data). South Korea (domestic sales alone): National Statistical Office, South Korea; World Population Prospects, 2008 Revision, United Nations, Department of Economic and Social Affairs (population data).

WHO guidelines, which state that approaches other than 100\% smoke-free environments, including ventilation, air filtration and designated smoking areas, have repeatedly been shown to be ineffective. ${ }^{39}$

Fourth, rebuilding of the administrative power structure is essential to protect tobacco control measures from interference by the tobacco industry. Each of the countries examined in the present study has a substantially state-owned tobacco company. The three counties have a history of promoting the tobacco industry as a national policy; each country has a legislative system to manage tobacco cultivation, production and sales. The Ministry of Finance of each country has authority over the whole industry. As previously reported for Japan, ${ }^{61}$ the tobacco industry in these countries is able to interfere in the drafting of new policies. The tobacco companies also promote a clean image of their activities through large-scale media campaigns, which counter efforts to denormalise the industry. However, in each country, government does hold majority control over the tobacco industry. Therefore, with sufficient political will it would be possible to use existing policy instruments to develop and implement long-term plans for reducing tobacco consumption and transforming the tobacco business. The three East Asian countries need to restructure their administrative frameworks, historically established to foster the tobacco industry, with the aim of improving their citizens' health.

A model in East Asia is Taiwan. The tobacco epidemic situation in Taiwan is similar to those in the three countries analysed. A large-scale survey in Taiwan indicated that the smoking prevalence is higher among men than among women, and that low quit rates among men and the high exposure to passive smoking among women and young children at home are of particular concern. ${ }^{62}$ However, the Taiwanese government passed the Tobacco Hazard Prevention Act in 1997, through which indoor places became partially smoke free. In 2002, the government started the Outpatient Smoking Cessation Services programme, and levied a health and welfare surcharge on each pack of cigarettes. ${ }^{63}$ Amendment of the Act in 2009 strengthened the legislation by extending smoke-free areas to almost all enclosed workplaces and public places, adding graphic health warnings to cigarette packages, and totally banning tobacco advertising, promotion, and sponsorship as recommended by the FCTC. ${ }^{63}$

\section{East Asian collaboration}

Japan, China and South Korea have similarities in many aspects of their tobacco control efforts, suggesting the potential for policy coordination among these three countries in prioritising issues and target setting. The tobacco market in Taiwan was opened in 1987 and that in South Korea in 1988. Since then, JT has gained a considerable market share in Taiwan and South Korea. ${ }^{64}$ China joined the World Trade Organisation in 2001 and the China National Tobacco Corporation has since made inroads into overseas markets. In anticipation of the possible cigarette market opening of mainland China, JT is now developing a plan to form an alliance with the Chinese tobacco industry. ${ }^{65}$ For the public health of the East Asian region, collaboration has been promoted on a research basis, ${ }^{66} 67$ but not sufficiently in terms of policy development and advocacy efforts. The FCTC Parties' reports showed that Japan, China and South Korea had been inactive in collaborating with each other. $^{46-48}$ To take action against tobacco industry activities that extend beyond national boundaries, international collaboration is essential, ${ }^{68}$ from global and local perspectives.

\section{Limitations}

This study has several limitations. First, not all of the survey data were up to date or nationally representative. Second, the surveillance period and definitions of evaluated items were not necessarily consistent between countries. Not all of our arguments can be fully supported by quantitative data, particularly regarding the tobacco industry interference in government policies. Finally, we did not fully analyse the background and/or historical factors affecting the current situation in the three countries. Future research should explore why the observed similarities and differences exist.

\section{CONCLUSION}

Our analysis of quantitative data and information obtained from international and domestic sources indicates an urgent need for the following set of tobacco control policies in East Asia: raising cigarette prices in combination with media campaigns targeting adult men; developing a multi-component quitting assistance system that includes telephone support and provides free cessation drugs; legislation for smoke-free workplaces and public places; and rebuilding the administrative structure to protect proposed measures from tobacco industry interference. The importance of these four approaches should be reaffirmed by all policymakers in East Asia. 
Key messages

- East Asia is one of the world's largest tobacco epidemic regions.

- Our analysis indicates an urgent need for the following policies: raising cigarette prices in combination with media campaigns targeting adult males; developing a multicomponent quitting assistance system that includes telephone support and provides free cessation drugs; legislating smokefree workplaces and public places; and rebuilding the administrative structure to protect proposed measures from tobacco industry interference.

- The importance of these standard approaches should be reaffirmed by all policy makers in East Asia.

Contributors KK collected Japanese data, analysed all the data, and wrote the manuscript. JY collected Chinese data, SP and MKL collected South Korean data, and YLQ and MI organised the research group and provided overall discussion.

Funding This work was supported by grants-in-aid for the Third-Term Comprehensive Ten-Year Strategy for Cancer Control from the Ministry of Health, Labour, and Welfare, Japan (grant numbers: 201118014, 201220044).

Competing interests None.

Provenance and peer review Not commissioned; internally peer reviewed.

Open Access This is an Open Access article distributed in accordance with the Creative Commons Attribution Non Commercial (CC BY-NC 3.0) license, which permits others to distribute, remix, adapt, build upon this work non-commercially, and license their derivative works on different terms, provided the original work is properly cited and the use is non-commercial. See: http://creativecommons.org/ licenses/by-nc/3.0/

\section{REFERENCES}

1 Eriksen M, Mackay J, Ross H. The tobacco atlas. 4th edn. Atlanta: American Cancer Society, 2012.

2 Ikeda N, Saito E, Kondo N, et al. What has made the population of Japan healthy? Lancet 2011;378:1094-105.

3 Gu D, Kelly TN, Wu X, et al. Mortality attributable to smoking in China. N Engl J Med 2009;360:150-9.

4 Katanoda K, Marugame T, Saika K, et al. Population attributable fraction of mortality associated with tobacco smoking in Japan: a pooled analysis of three large-scale cohort studies. J Epidemiol 2008;18:251-64.

5 Wang JB, Jiang $Y$, Wei WQ, et al. Estimation of cancer incidence and mortality attributable to smoking in China. Cancer Causes Control 2010;21:959-65.

6 Liu BQ, Peto R, Chen ZM, et al. Emerging tobacco hazards in China:

1. Retrospective proportional mortality study of one million deaths. BMJ 1998;317:1411-22.

7 WHO. Report on the global tobacco epidemic, 2008: the MPOWER package. Geneva: World Health Organization, 2008.

8 WHO. Report on the global tobacco epidemic, 2009: implementing smoke-free environments. Geneva: World Health Organization, 2009.

9 Centers for Disease Control and Prevention. Global tobacco control. http://www.cdc gov/tobacco/global/ (accessed 18 May 2012)

10 Sussman S, Pokhrel P, Black D, et al. Tobacco control in developing countries: Tanzania, Nepal, China, and Thailand as examples. Nicotine Tob Res 2007;9(Suppl 3):S447-57.

11 Wu C, Thompson ME, Fong GT, et al. Methods of the International Tobacco Control (ITC) China Survey. Tob Control 2010;19(Suppl 2):i1-5.

12 The national health and nutrition survey in Japan 2003. Tokyo: Dai-ichi-Shuppan Publishing, 2005 (in Japanese).

13 China Centers for Disease Control and Prevention. Global Adult Tobacco Survey (GATS) China 2010 country report. http://nccd.cdc.gov/GTSSData/Ancillary/ DownloadAttachment.aspx?ID=862 (accessed 9 Apr 2013).

14 Ministry of Health, Welfare and Family Affairs. Korean National Health Nutrition Examination Survey 2010. Seoul: Ministry of Health, Welfare and Family Affairs, the Republic of Korea, 2011 (in Korean).

15 The national health and nutrition survey in Japan 2009. http://www.mhlw.go.jp/ bunya/kenkou/eiyou/h21-houkoku.html (accessed 18 May 2012) (in Japanese).

16 Katanoda $K$, Matsumura Y. National nutrition survey in Japan-its methodological transition and current findings. J Nutr Sci Vitaminol (Tokyo) 2002:48:423-32.
17 Report on chronic disease risk factor surveillance in China, 2007. Beijing: People's Medical Publishing House, 2007 [Chinese].

18 The national health and nutrition survey in Japan 2010. http://www.mhlw.go.jp/stf/ houdou/2r98520000020qbb.html (accessed 13 Feb 2012) (in Japanese).

19 Ohida T. Nationwide survey on adolescent smoking and drinking behavior in Japan, 2008 annual report. Grants-in-aid for the cardiovascular and lifestyle-related diseases from the Ministry of Health, Labour, and Welfare, Japan, 2010. Tokyo: Ministry of Health, Labour, and Welfare. (in Japanese).

20 Survey report on the health and risk behavior among Chinese youth, 2005. Beijing: Peking University Medical Press; 2007 (in Chinese).

21 Ministry of Education, Science and Technology, Ministry of Health and Welfare. Youth health risk behavior web-based survey, 2010. Republic of Korea: Ministry of Education, Science and Technology, Ministry of Health and Welfare, 2011 (in Korean).

22 The national health and nutrition survey in Japan 2008. http://www.mhlw.go.jp/ bunya/kenkou/eiyou/h20-houkoku.html (accessed 18 May 2012) (in Japanese).

23 Li Q, Hyland A, O'Connor $R$, et al. Support for smoke-free policies among smokers and non-smokers in six cities in China: ITC China Survey. Tob Control 2010;19 (Suppl 2): i40-6.

24 Ministry of Health, Labour and Welfare, Japan. Special survey on industrial safety and health survey on state of employees' health. http://www.e-stat.go.jp/SG1/estat/ eStatTopPortal.do (accessed 18 May 2012) (in Japanese).

25 The GTSS Collaborative Group. A cross country comparison of exposure to secondhand smoke among youth. Tob Control 2006;15(Suppl 2):ii4-19.

26 Osaki Y. Nationwide survey on adult smoking behavior and passive smoking exposure, 2010 Annual report. Grants-in-aid for the cardiovascular and lifestyle-related diseases from the Ministry of Health, Labour, and Welfare, Japan, 2011. Tokyo: Ministry of Health, Labour, and Welfare. (in Japanese).

27 The Chinese Association of Tobacco Control. Potential effects of tobacco taxation. Beijing: The Chinese Association of Tobacco Control, 2008 (in Chinese).

28 Japan Health Promotion \& Fitness Foundation. Cigarette sales in Japan. http://www. health-net.or.jp/tobacco/product/pd070000.html (accessed 18 May 2012) (in Japanese).

29 National Development and Reform Commission. Cigarette business risk assessment report 2008. Beijing: National Development and Reform Commission, 2008 (in Chinese).

30 Institute of Economics, National Agency for Tobacco Monopoly. China tobacco development report 2002. Beijing: Institute of Economics, National Agency for Tobacco Monopoly, 2002 (in Chinese).

31 Japan Tobacco Inc. Annual report 2011 for the year ended March 31, 2011. Tokyo: Japan Tobacco Inc., 2011 (in Japanese).

32 The Japanese Circulation Society, The Japan Lung Cancer Society, The Japanese Cancer Association, The Japanese Respiratory Society. Smoking cessation treatment guidelines, 4th edn. Tokyo: The Japanese Circulation Society, The Japan Lung Cancer Society, The Japanese Cancer Association, The Japanese Respiratory Society, 2010 (in Japanese).

33 China CDC Tobacco Control Office. Manual for brief smoking cessation intervention. Beijing: China CDC Tobacco Control Office, 2010 (in Chinese).

34 Ministry of Health and Welfare. Guidelines for professionals on medical treatment of smoking cessation. Seoul: Ministry of Health and Welfare, the Republic of Korea, 2005 (in Korean).

35 Smoking Cessation Services. Guidelines for health promotion program in public health center. Seoul: Smoking Cessation Services, Ministry of Health and Welfare, the Republic of Korea, 2011 (in Korean).

36 Japanese Government. Ordinance for enforcement of the tobacco industry law, 2003 (in Japanese).

37 Government of the Republic of Korea. Law for the promotion of nation's health 1995 (in Korean)

38 National Tobacco Control Office. 2009 China tobacco control report-pictorial warnings showing the truth of tobacco harm. Beijing: National Tobacco Control Office, Chinese Center for Disease Control and Prevention, 2009.

39 WHO. Framework convention on tobacco control guidelines for implementation. Articles 5.3, 8-14. Lyon: World Health Organization, 2011.

40 Malone RE. China's chances, China's choices in global tobacco control. Tob Control 2010;19:1-2

41 Gan Q, Glantz SA. Relationship between the Chinese tobacco industry and academic institutions in China. Tob Control 2010;20:12-19.

42 International Bank for Reconstruction and Development and The World Bank. Global purchasing power parities and real expenditures: 2005 international comparison program. Washington, DC: International Bank for Reconstruction and Development/The World Bank, 2008

43 Japan Tobacco Inc. Domestic cigarette sales from April to December 2010. http:/l www.jti.co.jp/investors/press_releases/2011/pdf/20110128_01.pdf (accessed 18 May 2012) (in Japanese).

44 Mackay J, Eriksen M, Shafey 0, et al. The tobacco atlas. 3rd edn. Atlanta: American Cancer Society, 2009.

45 Ministry of Health, Labour and Welfare, Japan. Survey of medical care activities in public health insurance. http://www.e-stat.go.jp/SG1/estat/eStatTopPortal.do (accessed 18 May 2012) (in Japanese). 
46 FCTC. FCTC Party's report (final), Japan. http://www.who.int/fctc/reporting/ party_reports/jpn/en/index.html (accessed 29 Nov 2012).

47 FCTC. FCTC Party's report (2nd), China. http://www.who.int/fctc/reporting/ party_reports/chn/en/index.html (accessed 29 Nov 2012).

48 FCTC. FCTC Party's report (2nd), the Republic of Korea. http://www.who.int/fctc reporting/party_reports/en/index.html (accessed 29 Nov 2012).

49 Center for Cancer Control and Information Services, National Cancer Center, Japan. Smoking prevalence. http://ganjoho.jp/public/statistics/pub/statistics06.html (accessed 11 Mar 2013) (in Japanese).

50 Ministry of Health, Welfare and Family Affairs of the Republic of Korea. Korean national health nutrition examination survey. http://knhanes.cdc.go.kr/knhanes/index. do (accessed 15 Mar 2013) [Korean].

51 Outline of the tax system revision in the fiscal year 2010. National Diet Library 2010;669.

52 Framework Convention Alliance. Guidelines for FCTC Article 6 (Price and tax measures to reduce the demand for tobacco)—why health ministries should support them. http://www.fctc.org/index.php?option=com_content\&view=article\&id=429: cop-4-guidelines-for-fctc-article-6\&catid=222: meeting-resources\&ltemid=230 (accessed 26 Jul 2012).

53 Hu T-w, Mao Z, Shi J, et al. Tobacco taxation and its potential impact in China. Paris: International Union Against Tuberculosis and Lung Disease, 2008.

54 Oh JK, Lim MK, Yun EH, et al. Cost and effectiveness of the nationwide governmentsupported Smoking Cessation Clinics in the Republic of Korea. Tob Control 2013;22: e73-7.

55 Community Preventive Services Task Force. Guide to community preventive services. Increasing tobacco use cessation. http://www.thecommunityguide.org/tobacco/ cessation/index.html (accessed 18 May 2012).

56 The health checkup system for metabolic syndrome. Kenporen preliminary report. Kenpo News No. 1879. 2009;19-20 (in Japanese).

57 Japan Health Insurance Association. Annual report for the fiscal year 2008 (Kyokai Kenpo 2008), 2009 (in Japanese).
58 Survey results of the health checkup system for metabolic syndrome. Material for the 6th Committee on the Health Checkup System for Metabolic Syndrome (18 Dec 2009). Tokyo: All-Japan Federation of National Health Insurance Organizations (Kokumin Kenko Hoken Chuo Kai), 2009 (in Japanese).

59 Katanoda K, Levy DT, Nakamura M, et al. Modeling the effect of disseminating brief intervention for smoking cessation at medical facilities in Japan: a simulation study. Cancer Causes Control 2012;23:929-39.

60 Community Preventive Services Task Force. Guide to community preventive services. Reducing exposure to environmental tobacco smoke: smoking bans and restrictions. http://www.thecommunityguide.org/tobacco/environmental/smokingbans.html (accessed 18 May 2012)

61 Levin MA. Smoke around the rising sun: an American look at tobacco regulation in Japan. http://papers.ssrn.com/sol3/papers.cfm?abstract_id=1691348 (accessed 26 Sep 2012)

62 Wen CP, Levy DT, Cheng TY, et al. Smoking behaviour in Taiwan, 2001. Tob Control 2005; 14(Suppl 1):i51-5.

63 Chang FC, Chung CH, Yu PT, et al. The impact of graphic cigarette warning labels and smoke-free law on health awareness and thoughts of quitting in Taiwan. Health Educ Res 2011;26:179-91.

64 Japan Tobacco Inc. Annual report 2012 for the year ended March 31, 2012. Tokyo: Japan Tobacco Inc, 2012

65 Kimura R, Leeds E. Interview with the President of Japan Tobacco Inc. Reuters Japanese News7 July 2007 (in Japanese).

66 Boffetta P, Hazelton WD, Chen Y, et al. Body mass, tobacco smoking, alcohol drinking and risk of cancer of the small intestine-a pooled analysis of over 500,000 subjects in the Asia Cohort Consortium. Ann Oncol 2012;23:1894-8

67 Asia Cohort Consortium. http://www.asiacohort.org (accessed 29 Nov 2012).

68 Bialous S Aguinaga, Peeters S. A brief overview of the tobacco industry in the last 20 years. Tob Control 2012;21:92-4. 